\title{
THE SPECIAL EFFECT OF INTEREST RATE CUTS ON HOUSING PRICES
}

\author{
Che-Chun LIN ${ }^{1}$, I-Chun TSAI ${ }^{*}$ \\ ${ }^{1}$ Department of Quantitative Finance, National Tsing Hua University, Hsinchu, Taiwan \\ ${ }^{2}$ Department of Finance, National University of Kaohsiung, Kaohsiung, Taiwan
}

Received 08 March 2020; accepted 22 January 2021

\begin{abstract}
This study uses theoretical models and empirical research to explain that interest rates affect the structure of housing price formation and correction rather than affect the price alone. In particular, when interest rates are substantially reduced, the correction of housing prices toward fundamentals is absent; in other words, a housing bubble is likely to occur. This study first illustrates a model for explaining home price behavior. Data from the Case-Shiller U.S. National Home Price Index between January 1975 and August 2020 are adopted to observe the behavior of home prices. The empirical results show that the correction and bubble behavior of U.S. home prices have exhibited significant structural changes. Variation in money supply fails to explain the structural changes, however, interest rate variation can significantly affect the structural changes. According to the results, when interest rates rise or fall slightly, the correction of home prices toward the equilibrium value is significant. However, when interest rates fall substantially, the bubble behavior of home prices is significant. For governments that adopt low interest rates to revitalize the economy, the results of this study provide special reference values. Governments should provide additional intervention in housing markets when an extremely low interest rate exists.
\end{abstract}

Keywords: home price behavior, home price bubble, rational bubbles, monetary policy, interest rate, money supply.

JEL Classification: E52, R30.

\section{Introduction}

The effect of monetary policy on home prices has been a crucial research topic in recent years. Previous studies have primarily observed three types of effects that monetary policies have on home prices. The first type of effects is caused by interest rates (McDonald \& Stokes, 2013; Robstad, 2018; Paul, 2020); the second type of effects is caused by monetary liquidity (Congdon, 2005; Gouteron \& Szpiro, 2005; Chung, 2006; Su et al., 2018; Ryczkowski, 2019; Wang et al., 2020); and the third type of effects is caused indirectly by credit channels (Gimeno \& Martínez-Carrascal, 2010; Park et al., 2010).

*Corresponding author. E-mail: ictsai@nuk.edu.tw

Copyright (c) 2021 The Author(s). Published by Vilnius Gediminas Technical University

This is an Open Access article distributed under the terms of the Creative Commons Attribution License (http://creativecommons. org/licenses/by/4.0/), which permits unrestricted use, distribution, and reproduction in any medium, provided the original author and source are credited. 
The effects of interest rates and liquidity are most frequently used to explain home price bubbles. For example, Shiller (2009) argues that long-term low interest rates result in skyrocketing home prices. By adopting the U.S. home price index, McDonald and Stokes (2013) find that the policy of low interest rates implemented by the Federal Reserve System during 2001-2004 can account for the bubble in the U.S. housing market at that time; in addition, the increasing interest rates in 2004-2006 entailed the collapse of the housing market. Guo and $\mathrm{Li}$ (2011) investigate the relationship between excess liquidity and home price bubbles in China during 1998-2010. The empirical results indicate that excess liquidity precedes home price bubbles. Tsai (2015a) employs the U.S. home price index from January 1999 to August 2012 to discuss if monetary liquidity is related to bubbles in the U.S. housing market. The results show that the formation of home price bubbles is substantially related to money supply yet unrelated to interest rates.

Interest rates affect home prices mainly for two reasons. First, the cost of a house purchase is directly influenced by the level of interest rate because most people buy a house through mortgage, which provides financial intermediation. Second, when house value is converted to cash flow, market interest rate affects discount rate. However, the two reasons only account for the effects of interest rates on reasonable home prices and fail to explain why interest rate changes cause an unbalanced housing market (i.e., bubbles) and irrational home price behavior.

The effects of monetary liquidity explicitly explain how money supply results in asset price bubbles. If money supply considerably increases and fails to flow into real economic activities, it leads to excess liquidity. In this situation, the market has excessive money for an insufficiently low number of houses, thus creating home price bubbles. Interest rates and liquidity affect housing markets on different levels, which probably explains why previous studies have mainly identified liquidity as the factor of home price bubbles. However, central banks in various countries have started to use interest rates to stimulate economies in recent years. Therefore, governments must examine in detail and emphasize the possible effects of interest rates on the housing market.

In response to economic downturns, central banks in Japan and Europe have successively adopted the atypical monetary policy of negative interest rates in recent years. The COVID-19 pandemic that began in early 2020 has also caused the money supply in the US to move towards an unlimited amount of easing, and almost zero interest rates. According to traditional economic theories, negative interest rates will cause intermediation failure between savers and investors, which is unfavorable to long-term economic development. Accordingly, central banks generally avoid enforcing negative interest rates (thus an "atypical" policy). Therefore, past research rarely discussed the situation of extremely low-interest rates or even negative interest rates. When interest rate policies deviate from typical and conventional practices, one must analyze the effects of interest rates in greater detail. Therefore, this study investigates the effects of interest rates on the structure of the overall housing market, as well as the asymmetrical effects of rising and falling interest rates, to further analyze the long-term impacts posed by falling and negative interest rates on the housing market in the future.

This paper infers that both interest rates and liquidity in monetary policies affect home price bubbles, albeit at different levels. Through a theoretical model of asset prices, the pres- 
ent study suggests that interest rate changes may structurally affect home price behavior rather than merely increase or decrease them. Therefore, this study empirically estimates home price correction and bubbles, observes if the behavior of U.S. home prices has undergone structural changes in different periods, and finally verifies if the effects of interest rates are the primary factor that structurally changes home price behavior. In addition, interest rates affect home prices in an asymmetrical manner, and substantial interest rate cuts will tip the housing market off balance. The paper infers from previous studies that the nonsignificant effects of interest rates on home price bubbles may have originated from the failure of considering the asymmetrical effects produced by rising or falling interest rates. If the asymmetrical effects are not considered, the structural effect of interest rate changes over the housing market could be underestimated. The results in this article are more important for observing the effects of the "atypical" monetary policy after 2020; the research results warn that if governments continue to use extremely low-interest rates, they will undermine the stability of the housing market. The governments need to frequently monitor housing prices and to detect whether there are irrational behaviors in the housing markets.

In this paper, Section 1 introduces how home price behavior may vary with interest rate changes; Section 2 proposes the research model adopted in this study; Section 3 presents samples and empirical results, and last Section concludes this study.

\section{Literature review and theoretic framework}

Generally, variations in asset prices over time can be divided into two types, namely, serial correlation and mean reversion. Serial correlation is unrelated to fundamental factors and is regarded as the irrational behavior of home prices or home price bubbles. By contrast, home prices behave rationally when they correct themselves according to fundamental factors (i.e., mean reversion). Case and Shiller (1989) find that the U.S. housing market is irrational because home prices in the market exhibit serial autocorrelation. Case and Shiller (2003) point out that during a housing price bubble, the expectation of large price increases may have a strong impact on demand if people think that home prices are very unlikely to fall. A period of rapid house price growth can cause the rising expectations of future capital gains, resulting in the momentum (serial correlation) in house-price changes.

Malpezzi (1999) presents evidence to show that home prices tend to correct themselves toward the equilibrium price. Capozza et al. (2004) and Gao et al. (2009) analyze home price changes that are characteristic of serial correlation and mean reversion in different areas or periods. The most common procedure for analyzing the rational and irrational behavior of home prices is using fundamental factors to estimate the equilibrium home price and then establishing an error correction model on the basis of the price. Abraham and Hendershott (1996), Capozza et al. (2002), and Capozza et al. (2004) proposed a basic error correction model for simultaneously measuring the price behavior of serial correlation and mean reversion. Afterward, multiple studies (e.g., Li, 2015; Tsai, 2015a) have employed this basic model to analyze different home price characteristics and related topics about the housing market.

Let $P h$ be home price and $P h_{f}$ denote the equilibrium home price level. As expressed as follows, fundamental factors are used to estimate the equilibrium home price in this study. 
This paper uses a brief rent-or-buy problem to illustrate the mechanism by which house prices will be corrected towards equilibrium. Himmelberg, Mayer, and Sinai (2005) pointed out that people will choose whether to rent or to buy a house based on cost. For renters, the cost is rent; for buyers, besides paying the principal and interest of the house price, also have to pay for all housing-related costs during the holding period. Therefore, the rent-and-buy theory assumes that if there are no other restrictions of markets (such as borrowing restrictions), the housing market and the rental market are mutually substituted, that is, when the no-arbitrage equilibrium is reached, the rent paid by the renters for one period will be equal to the cost of buying and holding the house for one period, namely:

$$
R_{t}=P_{t} \times U C_{t},
$$

where $R C_{t}$ represents the rental cost on time $t, P_{t}$ denotes the house price on time in $t$, and $U C_{t}$ is the user cost per housing capital on time $t$. The cost of house users includes the interest that needs to be paid for owning the house, the related taxes (such as house tax and land value $\operatorname{tax}$ ) that need to be paid for holding the house, the house repair expenses due to the depreciation, and the expected capital gains. Therefore, the user cost can be described as follows:

$$
U C_{t}=r_{t}^{r m}+\omega+\delta+\gamma-g
$$

where $r_{t}^{r m}$ is the loan interest rate, $\omega$ is the tax burden of holding the house, $\delta$ is the house depreciation rate, and $g$ is the expected changing rate of house prices. When there is a balanced relationship between the rental market and the housing market, the cost of holding a house for one period should not exceed the rent for one period. If the cost of use by the owner increases, but the rent does not increase, the public will think that buying is not as good as renting. As a result, they tend to rent houses, and house prices will fall for correction, but rents will rise instead. Therefore, the rent-or-buy decisions of the public would cause a mechanism by which house prices will be corrected towards equilibrium. Combining Eqs (1) and (2), the following equilibrium conditions are obtained:

$$
P h_{t}^{*}=R_{t} / U C_{t} .
$$

Real rent is a part of the household's consumption, so it will be affected by income $\left(Y_{t}\right)$ and unemployment rate $\left(U R_{t}\right)$, and after adjusted by the inflation rate $\left(C P I_{t}\right)$, the function of nominal rent can be obtained:

$$
R_{t}=F\left(Y_{t}, U R_{t}, C P I_{t}\right)
$$

Except for the loan interest rate, the other variables in Eq. (2) will not change in a shortterm period, therefore many studies have assumed them as a constant (Zorn, 1988; Bourassa \& Yin, 2008). Therefore, this study can use the three major macroeconomic variables, namely, personal income, unemployment rate, and consumer price index, as the fundamental variables of home prices:

$$
P h_{f, t}=F\left(Y_{t}, U R_{t}, C P I_{t}\right) .
$$

The deviation between a home price and its fundamental value is $\varphi$. If the home price can converge to the fundamental value, $\varphi$ should be stationary. This study uses the error correction model developed by Capozza et al. (2004), and the model is expressed as follows: 


$$
\Delta P h_{t}=a \Delta P h_{t-1}+b \varphi_{t-1}+c \Delta P h_{f, t} .
$$

In Eq. (6), the first component refers to the irrational autocorrelation of home prices and is thus the bubble component, where $a$ represents the level of serial correlation (i.e., bubble). The second component is for assessing error correction, where the correction of home price behavior toward equilibrium is measured. $\varphi_{t-1}=P h_{t-1}-P h_{f, t-1}$ is an equilibrium error, a positive $\varphi_{t-1}$ indicates that home prices in the previous period have exceeded the equilibrium level and should be corrected downward in the present period. In this case, a significantly negative $b$ confirms a behavior of mean reversion in home prices. The third component refers to new impacts on home prices, where is the contemporaneous adjustment of prices to current shocks.

The definitions proposed by Gilles and LeRoy (1992) for fundamental value and bubble component are substituted into (6) as follows:

$$
P h_{t}=P h_{f, t}+\varphi_{t}=E_{t}\left[\sum_{\lambda=t+1}^{\infty} \frac{F_{\lambda}}{(1+r)^{\lambda-t}}\right]+\lim _{T \rightarrow \infty} E_{t}\left[\frac{B_{t}}{(1+r)^{T}}\right],
$$

where $r$ is the discount rate, and $F$ denote cash flows. Eq. (7) suggests that the fundamental value of housing is the sum of the discounted value of expected future cash flows $(F) . B_{t}$ is the bubble component on time $t$. This equation indicates that home price is determined by fundamental value and equilibrium error. Fundamental value is derived from the expected discounted value of future cash flows, whereas equilibrium error is the expected discounted value of future bubbles. According to Blanchard and Watson (1982), this paper defines a rational bubble of the form:

$$
B_{t-1}=\left\{\begin{array}{l}
\frac{\pi B_{t}}{1+r_{B}}+v_{t-1}, \text { with probability } \pi \\
v_{t-1}, \text { with probability } 1-\pi
\end{array} .\right.
$$

The bubble can burst in any period with the probability $1-\pi$, and if it does not burst, it grows at a rate $\frac{1+r_{B}}{\pi}-1 . v_{t}$ is a white noise process. According to Eq. (7), when the expected value of future cash flows and the expectation of home price bubbles remain unchanged, changes in discount rate change equilibrium home price and bubble component, altering home prices. However, this relationship only reveals that interest rates affect the rise and fall of home prices and does not explain why interest rate changes can alter home price behavior and direct it toward equilibrium or disequilibrium. Two conditions are discussed in the following subsections to elaborate on why interest rate changes may affect and structurally alter home price behavior.

\subsection{Expectation of rational bubbles}

Scherbina and Schlusche (2014) determine the conditions for a rational bubble to exist, arguing that the home price bubble can be prevented from bursting only if the expected growth rate of the bubble is equal to the discount rate (i.e., $\frac{1+r_{B}}{\pi}-1=r$ ). Since, when the bubble's 
rate of growth is lower than the discount rate, the present value of the bubble is zero, and the bubble will not exist; when the growth rate of bubble is higher than the discount rate, the present value of the bubble is infinite, and thus bubble cannot exist.

When the discount rate is adjusted with market interest rates, home prices would behave differently if the expected growth rate of the bubble is not adjusted accordingly. For example, when the discount rate simultaneously rises with interest rate, the bubble does not form and home price begins a continuous downward correction if the increase in the expected bubble growth rate is smaller than that in the discount rate (i.e., $\frac{1+r_{B}}{\pi}-1<r$ ). Conversely, a sudden drop in interest rate and discount rate increases the possibility of home price bubble. Therefore, the paper infers that when the expected bubble growth rate is adjusted at a slower pace, rising interest rates will strengthen the correction behavior of home prices, whereas falling interest rates will facilitate the continuous rise of home prices. This process characterizes the autocorrelation behavior of home prices.

Ferrero (2015) indicates that skyrocketing home prices and current fiscal deficits in the United States are mainly caused by excessively low interest rates and stagnating exchange rates. Kim and Min (2011) investigate the housing market bubbles in South Korea during 1986-2003 and find that the level of home price bubbles decreases with rising interest rates. These findings correspond with the present study's inference that an increase in interest rates reduces the level of housing market bubbles, whereas a decrease in interest rates may cause home prices to rise irrationally.

\subsection{Rent rigidity}

As different from the situation described in the previous subsection, this paper hypothesizes that in rational expectations, discount rates adjust themselves simultaneously with interest rate changes in the market, the expectation of home price bubbles varies with market interest rates, and interest rate changes do not affect the variations of rational bubbles:

$$
\lim _{T \rightarrow \infty} E_{t}\left[\frac{B_{t+T}\left(r_{t}\right)}{\left(1+r_{t}\right)^{T}}\right]-\lim _{T \rightarrow \infty} E_{t-1}\left[\frac{B_{t-1+T}\left(r_{t-1}\right)}{\left(1+r_{t-1}\right)^{T}}\right]=0 .
$$

However, asset cash flows may not change instantaneously. For example, if the future cash flow of a house property is derived from rent, the regular adjustment of the lease would result in rigid cash flows. If cash flows are fixed in the short term, the dynamic adjustment of home prices is expressed as follows:

$$
\Delta P h_{t}=P h_{f, t}-P h_{f, t-1}=E_{t}\left[\sum_{\lambda=t+1}^{\infty} \frac{\bar{F}}{\left(1+r_{t}\right)^{\lambda-t}}\right]-E_{t-1}\left[\sum_{\lambda=t}^{\infty} \frac{\bar{F}}{\left(1+r_{t-1}\right)^{\lambda-t-1}}\right] .
$$

When $\Delta r_{t}<0$, home prices are adjusted positively. By contrast, if rents remain rigid, falling interest rates would cause home prices to rise continuously until rents fall as well. Before rents reflect the change in interest rates, the continuously rising home prices deviate 
from and are unrelated to fundamentals. Therefore, the rising home prices at this stage are regarded as the autocorrelation behavior of a bubble.

Rent rigidity has been verified by numerous studies. For example, Genesove (2003) explores apartment rents in the United States and finds that 29\% of the rent in his 1974-1981 sample remained the same for one year. Shimizu et al. (2010) collect more than 700,000 housing rents in Japan in the past 20 years and determine that rent rigidity in Japan is three times that in the United States. In other words, $90 \%$ of the rent in the samples has remained unchanged annually. Sommer et al. (2013) investigate why U.S. home prices have grown rapidly and rents have remained stagnant during 1995-2006. They find that low interest rates can significantly explain the rising ratio of home price to rent in the United States during this period. Based on framing effect theory, Tsai (2020) proposes a new explanation for housing rent price rigidity.

According to the aforementioned two situations, this study proposes that interest rates not only cause home prices to fall or rise, but also significantly affect the variation in home price behavior. Therefore, this study empirically explores and verifies if interest rate variation is the critical variable that changes home price behavior.

\section{Empirical models}

Kishor and Marfatia (2017) analyze the dynamic relationships among the housing prices, incomes, and interest rates of 15 countries and reveal the cointegration relationships of housing prices with incomes and interest rates among most countries over a long period. If disequilibrium occurs in these relationships, housing prices vary to correct the disequilibrium relationships. Kishor and Marfatia use the stability of the price-income ratio (PIR) to infer an equilibrium relationship between housing prices and incomes. Previous studies, such as those by Lin et al. (2014) and Zhang et al. (2016), adopted the housing affordability concept to infer the stability of the PIR, assuming that an integration relationship exists between housing prices and incomes. The concepts of the stability of PIR and housing affordability indicate that when incomes do not grow considerably while housing prices increasing excessively, people's financial burdens increase, thereby reducing people's demand for purchasing housing. People rent to reduce their economic burdens, which causes housing prices to decrease.

Many studies have adopted this perspective to infer the equilibrium housing price (i.e., PIR model) and examine whether housing bubbles exist (André et al., 2014; Pavlidis et al., 2016). Kishor and Marfatia (2017) proposed that when the housing price exceeds , people will consider the housing burden excessively high and reduce their intention to purchase housing. By the model this paper illustrated in Section 3, in addition to the fundamental factor of incomes, this study considers other variables that can be used as fundamental factors of housing prices, as proposed by other studies, to facilitate a comprehensive analysis. Miles and Pillonca (2008) develop a simple economic framework to estimate the likely contributions of fundamental factors, such as changes in real incomes and population growth, to house price appreciation. Macroeconomic variables that relate to the performance of the economy or the output, such as personal income and unemployment rate, would influence the housing market. Many early studies (e.g., Ibbotson \& Siegel, 1984; Hartzell et al., 1987; 
Kuhle, 1987; and Rubens et al., 1989) propose that real estate provides a useful hedge against inflation. Hence, the inflation rate plays an important role in the demand for housing or real estate investments. Moreover, previous studies of the U.S. housing market have determined that these macroeconomic variables can significantly affect the fundamentals of the housing market and equilibrium home price (e.g., Gallin, 2006; Mikhed \& Zemcík, 2009; Kallberg et al., 2014; Tsai, 2015a).

Thus, the study incorporates unemployment rate and consumer price index into the PIR model. Therefore, as illustrated in Eq. (5), this study uses three major macroeconomic variables, namely, personal income, unemployment rate, and consumer price index, as the fundamental variables of home prices. Subsequently, this paper adopts the error correction model in Eq. (11) to estimate home price behavior:

$$
\Delta P h_{t}=a \Delta P h_{t-1}+b \varphi_{t-1}+c \Delta P h_{f, t}+\varepsilon_{t} .
$$

If the model in Eq. (11) can estimate well the behaviors of home prices and rational bubbles, $\varepsilon_{t}$ should be follow the white noise process just like $v_{t}$ does. To objectively measure if home price behavior has undergone structural changes during the data period, this study first employs the regression model with multiple breaks proposed by Bai and Perron (1998, 2003) to conduct global optimization procedures.

Now the paper considers the model with $T$ periods and $n$ potential breaks (producing $n+1$ regimes). In regime $i$ there are the observations $T_{i}, T_{i}+1, \ldots, T_{i+1}-1$. And the model can be obtained:

$$
\Delta P h_{t}=\sum_{i=1}^{n} a_{i} \Delta P h_{t-1}+\sum_{i=1}^{n} b_{i} \varphi_{t-1}+\sum_{i=1}^{n} c_{i} \Delta P h_{f, t}+\varepsilon_{t} .
$$

Bai and Perron (1998) and Bai and Perron (2003) develop the global optimization procedures for identifying the $n$ multiple breaks which minimize the sums-of-squared residuals of the regression model.

This study uses Eq. (12) to examine if home price correction and bubble behavior have undergone structural changes and subsequently determines if interest rates are the critical variable that induces changes in home price behavior. The following threshold regression (TR) model is employed in this study to estimate the structural effect of interest rates on home prices.

Let $\Delta r_{t}$ be the observable threshold variable, which strictly increasing threshold values ( $q_{1}<q_{2}<\cdots<q_{m}$ ) such that the variables in regime $i$ if and only if: $q_{i} \leq \Delta r_{t}<q_{i+1}$, where $q_{0}=-\infty$ and $q_{m+1}=\infty$. Thus the variables are in regime $i$ if the value of the threshold variable is at least as large as the -th threshold value, but not as large as the $i+1$-th threshold.

\section{Data and empirical results}

\subsection{Data}

This study adopts the Case-Shiller U.S. National Home Price Index from January 1975 to August 2020 to observe the behavior of U.S. home prices. Three U.S. macroeconomic variables, 
namely, personal income, unemployment rate, and consumer price index, are used to measure the fundamental level of home prices. In addition, to verify the effect of interest rates on home price behavior that is inferred in the theoretical framework of this study, average 30 -year mortgage rates are used as a proxy variable for the discount rate. To perform a robustness analysis, money supply (M2) is also used to observe if it affects home price behavior as well. The home price index data are obtained from the S\&P Dow Jones Indices Web site, and other data are derived from the Thomson Datastream database.

Table 1. Descriptive statistics and unit root tests

\begin{tabular}{|l|c|c|c|c|c|c|}
\hline \multicolumn{1}{|c|}{ Variable } & $\begin{array}{c}P h \\
\text { (index) }\end{array}$ & $\begin{array}{c}Y \\
\text { (Billions) }\end{array}$ & $\begin{array}{c}\text { UR } \\
(\%)\end{array}$ & $\begin{array}{c}\text { CPI } \\
\text { (index) }\end{array}$ & $\begin{array}{c}\text { M2 } \\
\text { (Billions) }\end{array}$ & $\begin{array}{c}r \\
(\%)\end{array}$ \\
\hline Mean & 106.78 & 8267.60 & 6.32 & 160.60 & 5678.78 & 7.92 \\
\hline Median & 86.55 & 7250.20 & 5.90 & 161.40 & 3993.35 & 7.48 \\
\hline Maximum & 223.97 & 21061.90 & 14.70 & 259.90 & 18403.50 & 18.45 \\
\hline Minimum & 25.24 & 1312.30 & 3.50 & 52.10 & 906.30 & 2.94 \\
\hline Std. Dev. & 54.96 & 5152.83 & 1.73 & 59.89 & 4112.87 & 3.35 \\
\hline Skewness & 0.33 & 0.47 & 0.78 & -0.10 & 0.97 & 0.80 \\
\hline Kurtosis & 1.84 & 2.07 & 3.72 & 1.87 & 2.95 & 3.25 \\
\hline PP unit root test & & & & & \\
\hline \multirow{2}{*}{ In levels } & -1.29 & -0.15 & -3.12 & -2.16 & 4.53 & -2.71 \\
\cline { 2 - 7 } & $(0.89)$ & $(0.99)$ & $(0.10)$ & $(0.51)$ & $(1.00)$ & $(0.23)$ \\
\hline \multirow{2}{*}{ In differenced } & -5.05 & -36.85 & -22.70 & -12.10 & -8.70 & -15.72 \\
\cline { 2 - 7 } & $(0.00)$ & $(0.00)$ & $(0.00)$ & $(0.00)$ & $(0.00)$ & $(0.00)$ \\
\hline
\end{tabular}

Notes: The labels in the table are explained as follows: home price index, personal income, unemployment rate, consumer price index, money supply, and interest rate are represented by $P h$, $Y, U R, C P I, M 2, r$, respectively. PP tests are adopted for testing the null hypothesis of a unit root in the series. The lag length of the unit root models is selected by using the Schwarz information criterion. The entry in parenthesis stands for the p-value.

Simple statistics of the variables adopted in this study are presented in Table 1, and the time series plot of the data is illustrated in Figure 1. According to Figure 1, the greatest correction in the housing market in the 45 years from 1975 to 2020 occurred during the subprime mortgage crisis in 2007. The rate of return of the home price index was $-24 \%$ from July 2006 to December 2010. Correction of such a large scale has been rare in a stable housing market. Before the crisis, a downturn in the U.S. housing market only induced stagnant home prices between 1990 and 1993. Nevertheless, a large correction resulted in a large rebound. From January 2012 to December 2015, the home price index rose by 30.5\%. After the financial crisis of 2007 and 2008, the Federal Reserve System has adopted a fairly loose monetary policy and a low interest rate policy. These policies, make scholars question whether the rising home prices in the recent years have been caused by monetary policies. However, the substantial rise of the home price index may indicate another bubble or merely reflect the macroeconomic recovery. Previous studies have verified that falling interest rates are favorable to home price recovery. Therefore, it is important to know if a continuous fall 

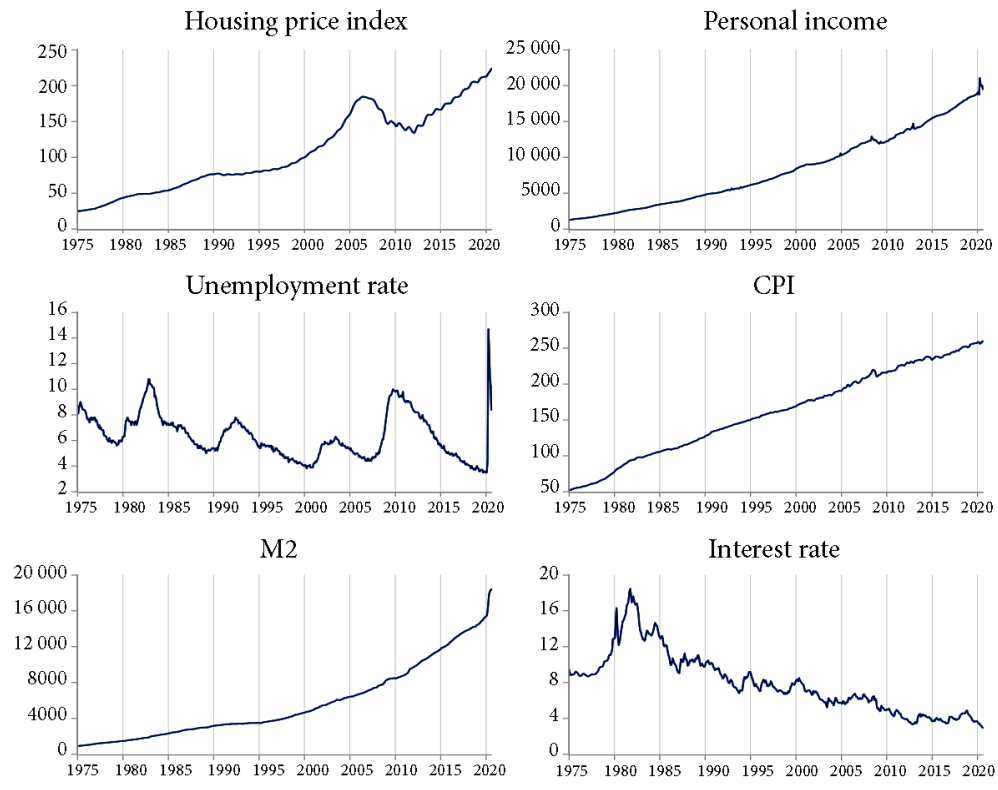

Figure 1. House prices and macroeconomic variables

in interest rates would change the behavioral structure of home prices, disrupt the original tendency of home price behavior toward rationality, and induce a relapse into the development of a bubble.

Judging from the performance of the macroeconomic variables, the rebound of home prices during 2012-2015 may have reflected an increase in people's income because personal income continuously rose and unemployment rate fell considerably during this period. Particularly, the unemployment rate decreased from 10\% in October 2009 to only 5\% in October 2015. In other words, people's economic conditions improved greatly in 2015, which substantially reduced mortgage default rates and increased the demand for houses, thus causing home prices to rebound.

This study adopts two variables, namely, interest rates and money supply, to observe the effects of monetary policies on home price behavior. Average 30-year mortgage rates and M2 money supply are used to measure the cost of raising a mortgage. Figure 1 shows that the Federal Reserve System implemented the first wave of quantitative easing monetary policies in March 2009, and consequently, money supply was observed to grow substantially in 2009 and 2010. Mortgage rates fell to the lowest (i.e., only 3.67\%) in January 2015. After rescue policies were successively launched, mortgage rates slightly rose in the second half of 2015.

Subsequently, the natural logarithms of the data were used in the empirical procedure. Table 1 presents the results of the Phillips-Perron (PP) unit root test. In addition, Table 1 shows that all the time series of the variables adopted in this study are I(1) series. In other words, all the results yielded by using the test statistics of original time series in a unit root test fail to significantly reject the null hypothesis of a unit root. However, when the variables that are differenced once are used in the unit root test, all the test statistics significantly reject the null hypothesis of a unit root. 


\subsection{Fundamental value of home prices}

Both home prices and fundamental variables are nonstationary data, namely, they are I(1) series. Subsequently, the paper conducts a cointegration test to test if a long-term equilibrium exists between home prices and fundamental variables. If the variables are significantly cointegrated, home prices would correct themselves toward the equilibrium value (i.e., fundamental level) in the long run. In this case, the fundamental level refers to the reasonable home price level; therefore, this study can continue to estimate $P h_{f}$ and home price behavior. The maximum likelihood estimation proposed by Johansen $(1988,1991)$ and Johansen and Juselius (1990), namely, the cointegration test that enables the estimation of multiple variables, is used in this study. As Table 2 shows, the empirical test incorporates other macroeconomic variables into the PIR model proposed by André et al. (2014) and Pavlidis et al. (2016). The PIR model investigates whether the housing burden is excessively high (whether an equilibrium relationship exists between housing prices and incomes) to determine whether housing bubbles exist. The model tested in this paper considers, in addition to the association between housing prices and housing affordability, the potential effects of other factors on housing prices.

Table 2 presents the estimates derived from the trace test and max-eigen test. The results indicate that home prices are in a significant long-term equilibrium with personal income, unemployment rate, and consumer price index. This equilibrium did exist because the hypothesis of the nonexistence of cointegration vectors is significantly rejected; moreover, only one conintegration vector exists because the null hypothesis of the presence of only one cointegration vector cannot be rejected. The results in Table 2 support the modeling in (5), indicating that, in the long-run, house prices are influenced by economic performance.

Table 2. Unrestricted cointegration rank test

\begin{tabular}{|c|c|c|c|c|}
\hline \multicolumn{5}{|c|}{$\begin{array}{c}\text { The cointegrated relationship among home price index, personal income, unemployment rate, } \\
\text { and consumer price index }\end{array}$} \\
\hline $\begin{array}{l}\text { Hypothesized } \\
\text { No. of CE(s) }\end{array}$ & Eigenvalue & Trace statistic & $\begin{array}{l}0.05 \text { Critical } \\
\text { Value }\end{array}$ & $p$-value \\
\hline \multicolumn{5}{|l|}{ Method: Trace test } \\
\hline None & 0.0882 & 72.5437 & 47.8561 & 0.0001 \\
\hline At most 1 & 0.0236 & 22.3972 & 29.7971 & 0.2769 \\
\hline At most 2 & 0.0163 & 9.4475 & 15.4947 & 0.3256 \\
\hline At most 3 & 0.0010 & 0.5384 & 3.8415 & 0.4631 \\
\hline $\begin{array}{l}\text { Hypothesized } \\
\text { No. of CE(s) }\end{array}$ & Eigenvalue & $\begin{array}{l}\text { Max-Eigen } \\
\text { statistic }\end{array}$ & $\begin{array}{l}0.05 \text { Critical } \\
\text { Value }\end{array}$ & $p$-value \\
\hline \multicolumn{5}{|c|}{ Method: Maximum Eigenvalue test } \\
\hline None & 0.0882 & 50.1465 & 27.5843 & 0.0000 \\
\hline At most 1 & 0.0236 & 12.9497 & 21.1316 & 0.4569 \\
\hline At most 2 & 0.0163 & 8.9091 & 14.2646 & 0.2938 \\
\hline At most 3 & 0.0010 & 0.5384 & 3.8414 & 0.4631 \\
\hline
\end{tabular}

Notes: CEs denote the cointegrating equations. The table shows the results of testing the cointegrated relationship among home price index and other macroeconomic variables. 
Estimation results (Table 2) reveal a long-term equilibrium relationship between housing prices and the three macroeconomic variables, and only one integration relationship is present. The results in Table 2 show that there is an adjustment mechanism for the housing market. When housing prices exceed the estimated standard in the integration relationship, the housing burden on people - in consideration of their financial status - increases. In response to pressure resulting from the burden, people choose to reduce housing purchases, thus causing declining demand in the housing market and decreasing housing prices. On the other hand, when housing prices exceed the equilibrium value, indicating the cost of use by the owner is too high, the public will think that buying is not as good as renting. As a result, they tend to rent houses, and house prices will fall for correction. Therefore, when housing prices are above the estimated level, the housing purchase behavior triggers the adjustment mechanism of the housing market and results in a correction of housing prices. The paper continues to estimate the equilibrium home price based on the significant long-term equilibrium in Table 2 . The nonstationary variables adopted in this study may result in the problem of spurious regression when they are directly used to estimate the relationship between the variables. Recently, the fully modified estimation is a common method that can directly use nonstationary data to explore information implied in long-term relationships. Therefore, this study employs the fully modified ordinary least squares (FMOLS) to estimate and obtain the unbiased long-term relationship between home prices and the macroeconomic variables.

Currently, an increasing number of studies have endeavored to develop a method that can estimate the relationship between nearly integrated regressors. FMOLS was proposed by Phillips and Hansen (1990) to provide optimal estimates of cointegrating regressions. Phillips (1995) pointed out that the method modifies least squares to account for serial correlation effects and it could deal with the endogeneity in the regressors that results from the existence of a cointegrating relationship.

Estimates of the long-term equilibrium between home prices and the variables are presented in Table 3. According to the results provided in Table 3, the equilibrium housing price can be estimated using the following equations:

$$
P h_{f, t}=0.7481 Y_{t}-0.0849 U R_{t}-0.0328 C P I_{t}-2.0652 \text {. }
$$

Table 3. Estimations for the equilibrium home price (FMOLS estimation)

\begin{tabular}{|l|c|c|c|c|}
\hline \multicolumn{1}{|c|}{ Variable } & Coefficient & Std. Error & $t$-Statistic & $p$-value \\
\hline$Y_{t}$ & $0.7481^{* * *}$ & 0.1244 & 6.0141 & 0.0000 \\
\hline$U R_{t}$ & $-0.0849^{* *}$ & 0.0399 & -2.1284 & 0.0338 \\
\hline$C P I_{t}$ & 0.0328 & 0.2110 & 0.1555 & 0.8764 \\
\hline Constant & $-2.0652^{* * *}$ & 0.1708 & -12.0914 & 0.0000 \\
\hline R-squared & 0.9733 & & & \\
\hline
\end{tabular}

Notes: This table shows the estimated results of the long-run relationship between home price index and fundamental variables. The estimated model is: $P h_{f, t}=F\left(Y_{t}, U R_{t}, C P I_{t}\right)$ where home price index, personal income, unemployment rate, and consumer price index are represented by $P h, Y, U R, C P I$, respectively. ${ }^{* *}$ indicates significance at the $1 \%$ level. ${ }^{* *}$ indicates significance at the $5 \%$ level. 


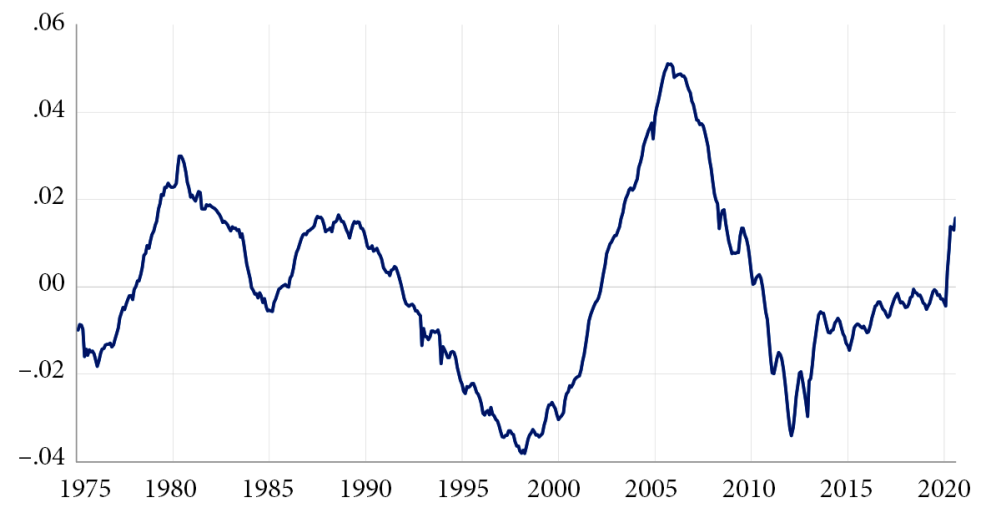

Figure 2. Deviations between the home price and its fundamental value

The error term derived from the cointegration in Table 3 is illustrated in Figure 2. The figure shows that the equilibrium error $\left(\varphi_{t}=P h_{t}-P h_{f, t}\right)$ has been negative during 1991-2001, indicating that home prices in this period were lower than the fundamental level. Since 1998, home prices have started to correct upward; however, the correction overly reflected positive information, and consequently the home prices exceeded the fundamental level considerably. By 2006, the overestimation of home prices became the most conspicuous. The housing market that began correction in 2007 was overly corrected. The home prices fell below the fundamental level and were not close to the level again until 2018.

Table 4. OLS estimations for home price behavior

\begin{tabular}{|c|c|c|c|c|}
\hline Variable & Coefficient & Std. Error & $t$-Statistic & $p$-value \\
\hline$\Delta P h_{t-1}$ & $0.9025^{\star * *}$ & 0.0185 & 48.7715 & 0.0000 \\
\hline$\varphi_{t-1}$ & $-0.0032^{* * *}$ & 0.0012 & -2.7449 & 0.0063 \\
\hline$\Delta P h_{f t}$ & 0.0217 & 0.0199 & 1.0896 & 0.2764 \\
\hline Constant & $0.0003^{\star *}$ & 0.0001 & 2.2773 & 0.0232 \\
\hline \multicolumn{2}{|l|}{ R-squared } & \multicolumn{2}{|c|}{ Log likelihood } & 2484.5610 \\
\hline \multicolumn{2}{|c|}{ Adjusted R-squared } & \multicolumn{2}{|c|}{$F$-statistic } & 826.1393 \\
\hline \multicolumn{2}{|c|}{ S.E. of regression } & \multicolumn{2}{|c|}{$\operatorname{Prob}(F$-statistic $)$} & 0.0000 \\
\hline \multicolumn{2}{|c|}{ Sum squared residual } & & & \\
\hline
\end{tabular}

Notes: The estimated model is: $\Delta P h_{t}=a \Delta P h_{t-1}+b \varphi_{t-1}+c \Delta P h_{f, t}+E+\varepsilon_{t}$ where $P h$ denotes the home price index, $P h_{f}$ denotes the fundamental home price, $\varphi_{t-1}=P h_{t-1}-P h_{f, t-1}$. E is the constant. ${ }^{* * *}$ indicates significance at the $1 \%$ level. ${ }^{* *}$ indicates significance at the $5 \%$ level.

\subsection{Home price behavior}

The results in Figure 2 indicate that home prices were sometimes in disequilibrium and sometimes corrected toward equilibrium during the 45-year sampling period. Afterward, 
this study estimates the home price behavior according to all the samples. The results listed in Table 4 show that home prices during the 45 years did exhibit irrational behavior of autocorrelation and correction. In Table 4, the coefficient $(a)$ of serial correlation is significant $(=0.9)$, indicating that irrational home price fluctuations are highly likely to persist. The coefficient $(b)$ of correction behavior is significant $(=-0.0032)$, revealing that home prices will continue to correct themselves toward the equilibrium value. Figure 2 shows that home prices exhibit a serial correlation behavior more obviously at some times and a correction behavior at other times. Therefore, this paper uses Table 5 to test if home price behavior has undergone structural changes during the sampling period. The results in Table 5 indicate that the home price behavior did undergo structural changes, and using the model involving one significant change can achieve an optimal goodness of fit. The most considerable structural change in home price behavior occurred in February 2009.

Table 5. Multiple breakpoint tests

\begin{tabular}{|c|c|c|c|c|}
\hline $\begin{array}{c}\text { Hypothesized } \\
\text { No. of breakpoint(s) }\end{array}$ & F-statistic & Scaled F-statistic & Critical Value \\
\hline 0 vs. 1 & 8.4366 & \multicolumn{2}{|c|}{33.7463} & 16.19 \\
\hline 1 vs. 2 & 1.5956 & \multicolumn{2}{c|}{6.3823} & 18.11 \\
\hline \multicolumn{2}{|c|}{ Break dates } & Sequential & Repartition \\
\hline \multicolumn{2}{|c|}{ 2009M02 } & 2009M02 \\
\hline
\end{tabular}

According to Table 6, the paper estimates that the home price behavior underwent structural changes during the data period. Table 6 shows that the home price behavior tended to become irrational from March 1975 to January 2009 because home prices in this period only exhibited conspicuous continuity (i.e., autocorrelation). The coefficient $(a)$ of serial correlation is significant $(=0.96)$, whereas the coefficient $(b)$ of correction behavior is not significant. Although the autocorrelation of home prices remained significant from February 2009 to August 2020, it has decreased to 0.80. The coefficient () of correction behavior is significant $(=-0.0170)$, showing that home prices higher than the equilibrium value will fall, whereas home prices lower than the equilibrium value will rise.

Table 6. The home price behavior underwent structural changes during the data period

\begin{tabular}{|l|c|c|c|c|}
\hline \multicolumn{1}{|c|}{ Variable } & Coefficient & Std. Error & $t$-Statistic & $p$-value \\
\hline 1975M3 - 2009M1 (407 obs) & $0.9603^{* * *}$ & 0.0242 & 39.7305 & 0.0000 \\
\hline$\Delta P h_{t-1}$ & -0.0022 & 0.0012 & -1.8285 & 0.0680 \\
\hline$\varphi_{t-1}$ & 0.0376 & 0.0251 & 1.5027 & 0.1335 \\
\hline$\Delta P h_{f, t}$ & -0.000003 & 0.0002 & -0.0175 & 0.9860 \\
\hline Constant & $0.8026^{* * *}$ & 0.0282 & 28.4417 & 0.0000 \\
\hline $2009 \mathrm{M} 2-2020 \mathrm{M} 8(139$ obs) & 0.0042 & -4.0131 & 0.0001 \\
\hline$\Delta P h_{t-1}$ & $-0.0170^{* * *}$ & &
\end{tabular}


End of Table 6

\begin{tabular}{|c|c|c|c|c|}
\hline Variable & Coefficient & Std. Error & $t$-Statistic & $p$-value \\
\hline$\Delta P h_{f, t}$ & -0.0550 & 0.0324 & -1.7019 & 0.0894 \\
\hline Constant & 0.0003 & 0.0003 & 1.0995 & 0.2720 \\
\hline \multicolumn{2}{|l|}{ R-squared } & \multicolumn{2}{|c|}{ Log likelihood } & 2501.1690 \\
\hline \multicolumn{2}{|c|}{ Adjusted R-squared } & \multicolumn{2}{|c|}{ F-statistic } & 378.3123 \\
\hline \multicolumn{2}{|c|}{ S.E. of regression } & & 0.0000 \\
\hline \multicolumn{2}{|c|}{ Sum squared residual } & \multicolumn{2}{|c|}{$\operatorname{Prob}(F$-statistic) } & \\
\hline
\end{tabular}

Notes: The table shows the results of using two sub-periods to estimate the following model: $\Delta P h_{t}=a \Delta P h_{t-1}+b \varphi_{t-1}+c \Delta P h_{f, t}+E+\varepsilon_{t}$ where $P h$ denotes the home price index, $P h_{f}$ denotes the fundamental home price, $\varphi_{t-1}=P h_{t-1}-P h_{f, t-1}$. E is the constant. ${ }^{* *}$ indicates significance at the $1 \%$ level.

In Table 7, threshold variables are tested to determine which variables have affected and induced structural changes in the home price behavior. This paper considers the possible effects of monetary policies on home price behavior and therefore simultaneously test if interest rates and money supply are threshold variables. Because threshold variables are required to be stationary, the paper tests the rate of change in interest rates and the growth rate of money supply. The error correction model is used to estimate if the rate of change in interest rates and the growth rate of money supply would cause structural changes in the coefficients $(a, b, c)$ of home price models.

The results in Table 7 indicate that the rate of change in interest rates is a threshold variable. In other words, the null hypothesis that the rate of change in interest rates cannot cause structural changes in home price behavior is significantly rejected (statistic $=21.44$ ). However, the null hypothesis that only one threshold exists is not significantly rejected (statistic $=6.15$ ), thus implying that the rate of change in interest rates is the factor for inducing structural changes in the coefficients $(a, b, c)$ of home price models, and that only one threshold exists. In other words, high and low rates of changes in interest rates result in different home price behavior. The threshold is estimated in Table 8 to clarify the effects of interest rates on home price behavior.

Table 7 also estimates if another variable for monetary policy, namely, the growth rate of money supply, is a threshold variable. According to the results in Table 7, the null hypothesis stating that the growth rate of money supply is not a threshold variable is not significantly rejected (statistic $=5.67$ ), indicating that money supply does not significantly cause changes in home price behavior. Multiple studies have found the effects of money supply on home price bubbles. For example, Tsai (2015a) determines that excessive monetary liquidity leads to home price bubbles; however, Tsai does not find that interest rates significantly affect home prices as well. The theoretical framework and empirical results of this study indicate that the possible reason for this contrast is that interest rates may affect the structure of home price behavior rather than the increase or decrease of home prices. The results of this study provide evidence that interest rate policies are crucial to home price bubbles.

To verify the effects of interest rates on home price correction and bubble behavior, this study continues to estimate the threshold regression model (Table 8). The results in Table 8 
show that home price behavior is divided into two states according to the rate of change in interest rates, and the threshold is -0.0167 . Therefore, the first state is specified by a rate of change in interest rates that is lower than $-1.67 \%$ (i.e., considerably falling interest rates); the second state is indicated by a rate of change in interest rates that is higher than $-1.67 \%$ (i.e., slightly falling, unchanged, or rising interest rates).

Table 7. Testing for threshold variable

\begin{tabular}{|l|c|c|c|}
\hline \multicolumn{1}{|c|}{ Threshold Test } & F-statistic & Scaled F-statistic & Critical Value \\
\hline Threshold variable: $\Delta r$ & 5.3604 & 21.4417 & 16.19 \\
\hline 0 vs. 1 & 1.5368 & 6.1473 & 18.11 \\
\hline 1 vs. 2 & 1.4198 & 5.6792 & 16.19 \\
\hline Threshold variable: $\Delta M 2$ & &
\end{tabular}

In the first state, the coefficient $(a)$ of serial correlation is significant $(=0.93)$, demonstrating significant irrational autocorrelation behavior in home prices. By contrast, the coefficient ( $b$ ) of correction toward equilibrium is not significant. Therefore, when interest rates fall considerably, home prices exhibit autocorrelation without correction, indicating that home price variation is inefficient in this interest rate environment. Both situations described in the theoretical framework of this study can explain the results shown in Table 8. In the first situation, when the home price bubble expected by the public does not correct downward with interest rates, home prices tend to exhibit upward divergence. In the second situation, when rents are rigid against a substantial downward adjustment of interest rates, home prices would reflect the gains of a falling discount rate. The more interest rates fall, or the longer rent rigidity remains, the more and the longer home prices are likely to deviate from fundamentals.

In the second state when interest rates do not fall considerably, the autocorrelation of home prices remains significant; however, the coefficient $(a)$ of serial correlation is 0.88 , which is smaller than the coefficient in the first state. The coefficient of correction toward equilibrium is significant $(=-0.0038)$, indicating that the rational behavior of correction toward equilibrium in home prices is significant. In the second state, interest rates may not vary substantially (e.g., stay unchanged, fall slightly, and rise slightly). According to the theoretical framework of this study, unadjusted bubble expectations and rent rigidity do not cause home prices to deviate from fundamentals, and therefore home prices still correct themselves in these situations.

However, interest rates may rise considerably in the second state without inducing the deviation of home prices that occurs when interest rates fall substantially. Contrarily, home prices tend to correct themselves toward equilibrium. The study views the difference as an indication of the asymmetrical effects of interest rates on home prices. According to the inference in the theoretical model of this study, this condition may result from the fact that the discount rate rises simultaneously with interest rates, thus reducing the level of increase in the growth rate of the expected bubble, causing home prices to start a continual downward 
Table 8. Asymmetric effects of interest rates on home price behavior

\begin{tabular}{|c|c|c|c|c|}
\hline Variable & Coefficient & Std. Error & $t$-Statistic & $p$-value \\
\hline \multicolumn{5}{|c|}{$\Delta r<-0.0167$ (168 obs) } \\
\hline$\Delta P h_{t-1}$ & $0.9302^{\star * *}$ & 0.0291 & 32.0187 & 0.0000 \\
\hline$\varphi_{t-1}$ & -0.0011 & 0.0021 & -0.5282 & 0.5976 \\
\hline$\Delta P h_{f, t}$ & 0.0708 & 0.0410 & 1.7275 & 0.0847 \\
\hline Constant & $-0.0005^{\star *}$ & 0.0002 & -2.1646 & 0.0309 \\
\hline \multicolumn{5}{|c|}{$-0.0167<=\Delta r \quad(378 \mathrm{obs})$} \\
\hline$\Delta P h_{t-1}$ & $0.8779^{* * *}$ & 0.0236 & 37.2397 & 0.0000 \\
\hline$\varphi_{t-1}$ & $-0.0038^{\star * *}$ & 0.0014 & -2.8104 & 0.0051 \\
\hline$\Delta P h_{f, t}$ & -0.0063 & 0.0226 & -0.2769 & 0.7820 \\
\hline Constant & $0.0008^{\star * *}$ & 0.0002 & 4.5490 & 0.0000 \\
\hline \multicolumn{2}{|l|}{ R-squared } & 0.8274 & Log likelihood & 2495.2300 \\
\hline \multicolumn{2}{|c|}{ Adjusted R-squared } & 0.8252 & $F$-statistic & 165 \\
\hline \multicolumn{2}{|c|}{ S.E. of regression } & 0.0025 & $\operatorname{Prob}(F$-statistic $)$ & \\
\hline Sum squared & & & & \\
\hline
\end{tabular}

Notes: The estimated model is: $\Delta P h_{t}=a_{1} D_{t} \Delta P h_{t-1}+b_{1} D_{t}\left(P h_{t-1}-P h_{f, t-1}\right)+c_{1} D_{t} \Delta P h_{f, t}+E_{1} D_{t}+$ $a_{2}\left(1-D_{t}\right) \Delta P h_{t-1}+b_{2}\left(1-D_{t}\right)\left(P h_{t-1}-P h_{f, t-1}\right)+c_{2}\left(1-D_{t}\right) \Delta P h_{f, t}+E_{2}\left(1-D_{t}\right)+\varepsilon_{t}$, where $P h$ denotes the home price index, $P h_{f}$ denotes the fundamental home price, $\varphi_{t-1}=P h_{t-1}-P h_{f, t-1}$. E is the constant. $D$ is a dummy variable, which equals to 1 when $\Delta r<-0.0167$; otherwise, $D$ is 0 . The threshold value $(-0.0167)$ is estimated endogenously. ${ }^{* *}$ indicates significance at the $1 \%$ level. ${ }^{* *}$ indicates significance at the $5 \%$ level.

correction. Consequently, the correction behavior of home prices tends to appear particularly in the second state. However, if the deviation of home prices is caused by rent rigidity, asymmetrical rent rigidity may account for such deviation. Rents tend to exhibit downward rigidity. When interest rates rise considerably, house owners do not have the incentive to maintain rigid rents. Therefore, house owners will increase the rent upon the expiration of the lease. Rent rigidity lasts for a shorter period, and the deviation of home prices is smaller in extent and shorter in time.

Finally, in order to verify the robustness of the empirical models, and to further test whether interest rates can be used as an instrumental variable for the state transition of house price behavior, this article uses the state switching model of Eq. (6) and uses the changing rate of interest rate to be as the instrumental variable that affects the state probability. Table 9 shows that changes in interest rates will significantly affect the states of house price behavior. Using the state switching model to estimate, it is also found that the home price behavior in the United States in the past 45 years can be divided into two states. The first is that the changes in home prices are only self-correlated and will not be corrected towards equilibrium; the second is that home prices are clearly towards equilibrium. The results in Table 9 are not only consistent with Table 8 , but also further verify that interest rates are a factor that affects changes in home prices. 
Table 9. Switching regression

\begin{tabular}{|c|c|c|c|c|}
\hline Variable & Coefficient & Std. Error & $z$-Statistic & $p$-value \\
\hline \multicolumn{5}{|l|}{ Regime 1} \\
\hline$\Delta P h_{t-1}$ & $0.9879^{\star * *}$ & 0.0281 & 35.1330 & 0.0000 \\
\hline$\varphi_{t-1}$ & -0.0007 & 0.0018 & -0.3942 & 0.6934 \\
\hline$\Delta P h_{f, t}$ & $0.0748^{* *}$ & 0.0338 & 2.2116 & 0.0270 \\
\hline Constant & $-0.0009^{* * *}$ & 0.0002 & -4.0491 & 0.0001 \\
\hline \multicolumn{5}{|l|}{ Regime 2} \\
\hline$\Delta P h_{t-1}$ & $0.7797^{\star \star \star}$ & 0.0338 & 23.0648 & 0.0000 \\
\hline$\varphi_{t-1}$ & $-0.0049^{* *}$ & 0.0019 & -2.5376 & 0.0112 \\
\hline$\Delta P h_{f, t}$ & -0.0300 & 0.0292 & -1.0288 & 0.3036 \\
\hline Constant & $0.0019^{\star * \star}$ & 0.0003 & 7.3975 & 0.0000 \\
\hline \multicolumn{5}{|l|}{ Common } \\
\hline $\ln \sigma$ & $-6.0633^{* * *}$ & 0.0339 & -178.9471 & 0.0000 \\
\hline \multicolumn{5}{|c|}{ Probabilities Parameters } \\
\hline Prob. $(\Delta r)$ & $40.8958^{\star * \star}$ & 14.6533 & 2.7909 & 0.0053 \\
\hline \multicolumn{2}{|c|}{ Mean dependent var. } & 0.0040 & ent var. & 0.0060 \\
\hline S.E. of regres & & & red & 0.0035 \\
\hline Durbin-Wats & & & ood & 2504.9120 \\
\hline
\end{tabular}

Notes: The estimated model is: $\Delta P h_{t}=a_{1} s_{1} \Delta P h_{t-1}+b_{1} s_{1} \varphi_{t-1}+c_{1} s_{1} \Delta P h_{f, t}+s_{1} E_{1}+a_{2} s_{2} \Delta P h_{t-1}+$ $b_{2} s_{2} \varphi_{t-1}+c_{2} s_{2} \Delta P h_{f, t}+s_{2} E_{2}+\varepsilon_{t}$, where $s_{t}$ is the state variable, $P h$ denotes the home price index, $P h_{f}$ denotes the fundamental home price, $\varphi_{t-1}=P h_{t-1}-P h_{f, t-1} . E$ is the constant. ${ }^{* *}$ indicates significance at the $1 \%$ level. ${ }^{* *}$ indicates significance at the $5 \%$ level.

Overall, the empirical results of this study have verified that interest rate variation affects home price behavior, and home prices tend to fall into disequilibrium or correct themselves anytime in the housing market when the economic environment involves a substantial decrease in interest rates. Previous studies have reported that interest rates affect housing prices (Fischer et al., 2019; Hanck \& Prüser, 2020; Valadkhani et al., 2019) and result in housing bubbles (Jordà et al., 2015; Moons \& Hellinckx, 2019). Other studies have identified that money supply affects housing prices (Su et al., 2019; Yin et al., 2020) and bubbles (Tsai, 2015b; Huang \& Shen, 2017). This study presents a new perspective to explain that interest rates affect the structure of housing price formation and whether prices are corrected toward the equilibrium.

\section{Conclusions}

Initially, this study establishes a model for explaining home price behavior, and subsequently hypothesizes that two situations, namely, the failure to adjust the expectation of rational bubbles in time and the existence of rent rigidity, would change home price bubbles or cor- 
rection behavior (when the discount rate is adjusted in an asset evaluation model). Different from previous literature, this study argues that interest rates not only affect the rise or fall of home prices, but may also induce structural changes in home prices. Average 30-year mortgage rates are adopted as the surrogate variable for the discount rate, and the Case-Shiller U.S. National Home Price Index is used as the surrogate variable for the performance of the U.S. housing market to verify the inference of this study that interest rate variation affects changes in home price correction or bubble behavior.

Data spanning 45 years from January 1975 to August 2020 are adopted. The empirical results of this study confirm that the correction and bubble behavior of U.S. home prices have undergone significant structural changes. Concerning monetary policy-related variables, although variation in money supply fails to explain such structural changes, interest rate variation can account for such changes. Interest rate variation is the threshold variable for the model of home price behavior (threshold $=-1.67 \%$ ), indicating that home price behavior is divide into two states according to the rate of change in interest rates. In the first state, the rate of change in interest rates is less than $-1.67 \%$, indicating that interest rates fall considerably; in the second state, the rate of change in interest rates is greater than $-1.67 \%$, revealing that interest rates fall slightly, remain unchanged, or rise.

Through the threshold model, the paper finds the asymmetrical effects of interest rate variation on home price behavior. When interest rates fall substantially, home prices exhibit significant bubble behavior; moreover, home prices continue to deviate without correcting themselves toward fundamentals. However, if interest rates rise or fall slightly, home prices exhibit significant correction toward the equilibrium value. The results of this study imply that two concerns must be considered when analyzing the effects of interest rates on the housing market, namely, the structural effect of substantially falling interest rates on home price behavior and the asymmetrical effects of the rise and fall of interest rates on home price behavior must be considered.

Currently, numerous countries worldwide have implemented interest rate policies to interfere with the market. Many countries have adopted policies maintaining an extremely low interest rate. Therefore, a comprehensive assessment of the effects of interest rates is crucial. Using an empirical model that fails to consider structural changes and asymmetrical effects may risk underestimating the effects of interest rates. Accordingly, this study suggests that not only the effects of interest rates on home prices but also their effects on other macroeconomic variables be estimated in detail. In addition, traders in the market are recommended to pay particular attention to the effects of a substantial decrease in interest rates on distorting the housing market. Previous studies have explained that interest rates and monetary policy affect housing prices and bubbles. This study provides a new perspective and presents the reasoning to illustrate that interest rates affect the structure of housing price formation, in turn affecting whether housing prices are corrected toward the equilibrium. The results indicate that when interest rates are considerably reduced, housing bubbles are likely to occur. According to these inferences, this paper recommends that the government provide additional intervention in housing markets when an extremely low interest rate exists.

During the study period of this paper, a negative nominal interest rate has not yet appeared, but since 2020, interest rates in various countries have been getting lower and lower, 
even close to zero, it is very likely that negative interest rates will occur in the future. Future research should discuss the effect of interest rate cuts under negative interest rates.

\section{Acknowledgements}

We are immensely grateful to Professor Martinkute Kaulienè (Managing Editor) and the two anonymous referees for the constructive comments of this paper.

\section{References}

Abraham, J. M., \& Hendershott, P. H. (1996). Bubbles in metropolitan housing markets. Journal of Housing Research, 7(2), 191-207. https://www.jstor.org/stable/24832859

André, C., Gil-Alana, L. A., \& Gupta, R. (2014). Testing for persistence in housing price-to-income and price-to-rent ratios in 16 OECD countries. Applied Economics, 46(8), 2127-2138. https://doi.org/10.1080/00036846.2014.896988

Bai, J., \& Perron, P. (1998). Estimating and testing linear models with multiple structural changes. Econometrica, 66(1), 47-78. https://doi.org/10.2307/2998540

Bai, J., \& Perron, P. (2003). Computation and analysis of multiple structural change models. Journal of Applied Econometrics, 18(1), 1-22. https://doi.org/10.1002/jae.659

Blanchard, O., \& Watson, M. (1982). Bubbles, rational expectations and financial markets. In P. Wachtel (Ed.), Crises in the economic and financial structure: Bubbles, bursts, and shocks. Lexington, MA. https://doi.org/10.3386/w0945

Bourassa, S. C, \& Yin, M. (2008). Tax deductions, tax credits and the homeownership rate of young urban adults in the United States. Urban Studies, 45(5-6), 1141-1161. https://doi.org/10.1177/0042098008089981

Capozza, D. R., Hendershott, P. H., \& Mack, C. (2004). An anatomy of price dynamics in illiquid markets: Analysis and evidence from local housing markets. Real Estate Economics, 32(1), 1-32. https://doi.org/10.1111/j.1080-8620.2004.00082.x

Capozza, D. R., Hendershott, P. H., Mack, C., \& Mayer, C. J. (2002). Determinants of real house price dynamics (NBER Working Paper No. 9262). https://doi.org/10.3386/w9262

Case, K. E., \& Shiller, R. J. (1989). The efficiency of the market for single-family homes. American Economic Review, 79(1), 125-137. https://www.jstor.org/stable/1804778

Case, K. E., \& Shiller, R. J. (2003). Is there a bubble in the housing market? Brookings Papers on Economic Activity, 2003(2), 299-362. https://doi.org/10.1353/eca.2004.0004

Chung, K. (2006). Asset prices and monetary liquidity in Korea. Journal of Korea Economic Studies, $17,257-287$.

Congdon, T. (2005). Money and asset prices in boom and bust (IEA Hobart paper No. 153). https://doi.org/10.2139/ssrn.839866

Ferrero, A. (2015). House price booms, current account deficits, and low interest rates. Journal of Money, Credit and Banking, 47(S1), 261-293. https://doi.org/10.1111/jmcb.12202

Fischer, M. M., Huber, F., Pfarrhofer, M., \& Staufer-Steinnocher, P. (2019). The dynamic impact of monetary policy on regional housing prices in the United States. Real Estate Economics, 1-30 (in Press). https://doi.org/10.1111/1540-6229.12274

Gallin, J. (2006). The long-run relationship between house prices and income: Evidence from local housing markets. Real Estate Economics, 34(3), 417-438.

https://doi.org/10.1111/j.1540-6229.2006.00172.x 
Gao, A., Lin, Z., \& Na, C. F. (2009). Housing market dynamics: Evidence of mean reversion and downward rigidity. Journal of Housing Economics, 18(3), 256-266. https://doi.org/10.1016/j.jhe.2009.07.003

Genesove, D. (2003). The nominal rigidity of apartment rents. Review of Economics and Statistics, 85(4), 844-853. https://doi.org/10.1162/003465303772815763

Gilles, C., \& LeRoy, S. F. (1992). Bubbles and charges. International Economic Review, 33(2), 323-339. https://doi.org/10.2307/2526897

Gimeno, R., \& Martínez-Carrascal, C. (2010). The relationship between house prices and house purchase loans: The Spanish case. Journal of Banking \& Finance, 34(8), 1849-1855. https://doi.org/10.1016/j.jbankfin.2009.12.011

Gouteron, S., \& Szpiro, D. (2005). Excess monetary liquidity and asset prices (Banque de France Working paper No. NER-E 131). https://doi.org/10.2139/ssrn.1703438

Guo, S., \& Li, C. (2011). Excess liquidity, housing price booms and policy challenges in China. China \& World Economy, 19(6), 76-91. https://doi.org/10.1111/j.1749-124X.2011.01267.x

Hanck, C., \& Prüser, J. (2020). House prices and interest rates: Bayesian evidence from Germany. Applied Economics, 52(28), 3073-3089. https://doi.org/10.1080/00036846.2019.1705242

Hartzell, D., Hekman, J. S., \& Miles, M. E. (1987). Real estate returns and inflation. Real Estate Economics, 15(1), 617-637. https://doi.org/10.1111/1540-6229.00407

Himmelberg, C., Mayer, C., \& Sinai, T. (2005). Assessing high house prices: Bubbles, fundamentals and misperceptions. Journal of Economic Perspectives, 19(4), 67-92. https://doi.org/10.1257/089533005775196769

Huang, J., \& Shen, G. Q. (2017). Residential housing bubbles in Hong Kong: Identification and explanation based on GSADF test and dynamic probit model. Journal of Property Research, 34(2), 108-128. https://doi.org/10.1080/09599916.2017.1321574

Ibbotson, R. G., \& Siegel, L. B. (1984). Real estate returns: A comparison with other investments. Real Estate Economics, 12(3), 219-242. https://doi.org/10.1111/1540-6229.00320

Johansen, S. (1988). Statistical analysis of cointegration vectors. Journal of Economic Dynamics and Control, 12(2-3), 231-254. https://doi.org/10.1016/0165-1889(88)90041-3

Johansen, S. (1991). Estimation and hypothesis testing of cointegration vectors in Gaussian vector autoregressive models. Econometrica, 59(6), 1551-1580. https://doi.org/10.2307/2938278

Johansen, S., \& Juselius, K. (1990). Maximum likelihood estimation and inference on cointegration - with applications to the demand for money. Oxford Bulletin Economics and Statistics, 52(2), 169210. https://doi.org/10.1111/j.1468-0084.1990.mp52002003.x

Jordà, Ò., Schularick, M., \& Taylor, A. M. (2015). Betting the house. Journal of International Economics, 96(S1), S2-S18. https://doi.org/10.1016/j.jinteco.2014.12.011

Kallberg, J. G., Liu, C. H., \& Pasquariello, P. (2014). On the price comovement of U.S. residential real estate markets. Real Estate Economics, 42(1), 71-108. https://doi.org/10.1111/1540-6229.12022

Kim, B. H., \& Min, H. G. (2011). Household lending, interest rates and housing price bubbles in Korea: Regime switching model and Kalman filter approach. Economic Modelling, 28(3), 1415-1423. https://doi.org/10.1016/j.econmod.2011.02.001

Kishor, N. K., \& Marfatia, H. A. (2017). The dynamic relationship between housing prices and the macroeconomy: Evidence from OECD countries. Journal of Real Estate Finance and Economics, 54, 237-268. https://doi.org/10.1007/s11146-015-9546-8

Kuhle, J. (1987). Portfolio diversification and returns benefits - Common stock vs. real estate investment trusts. Journal of Real Estate Research, 2(2), 1-9. https://www.jstor.org/stable/44095201

Li, Y. M. (2015). The asymmetric house price dynamics: Evidence from the California market. Regional Science and Urban Economics, 52, 1-12. https://doi.org/10.1016/j.regsciurbeco.2015.02.002 
Lin, Y.-J., Chang, C.-O., \& Chen, C.-L. (2014). Why homebuyers have a high housing affordability problem: Quantile regression analysis. Habitat International, 43, 41-47. https://doi.org/10.1016/j.habitatint.2014.01.013

Malpezzi, S. (1999). A simple error correction model of house prices. Journal of Housing Economics, 8(1), 27-62. https://doi.org/10.1006/jhec.1999.0240

McDonald, J. F., \& Stokes, H. H. (2013). Monetary policy and the housing bubble. Journal of Real Estate Finance and Economics, 46(3), 437-451. https://doi.org/10.1007/s11146-011-9329-9

Mikhed, V., \& Zemcík, P. (2009). Do house prices reflect fundamentals? Aggregate and panel data evidence. Journal of Housing Economics, 18(2), 140-149. https://doi.org/10.1016/j.jhe.2009.03.001

Miles, D., \& Pillonca, V. (2008). Financial innovation and European housing and mortgage markets. Oxford Review of Economic Policy, 24(1), 145-175. https://doi.org/10.1093/oxrep/grn005

Moons, C., \& Hellinckx, K. (2019). Did monetary policy fuel the housing bubble? An application to Ireland. Journal of Policy Modeling, 41(2), 294-315. https://doi.org/10.1016/j.jpolmod.2019.03.006

Park, S. W., Bahng, D. W., \& Park, Y. W. (2010). Price run-up in housing markets, access to bank lending and house prices in Korea. Journal of Real Estate Finance and Economics, 40(3), 332-367. https://doi.org/10.1007/s11146-008-9143-1

Paul, P. (2020). The time-varying effect of monetary policy on asset prices. Review of Economics and Statistics, 102(4), 690-704. https://doi.org/10.1162/rest_a_00840

Pavlidis, E., Yusupova, A., Paya, I., Peel, D., Martínez-García, E., Mack, A., \& Grossman, V. (2016). Episodes of exuberance in housing markets: In search of the smoking gun. Journal of Real Estate Finance and Economics, 53, 419-449. https://doi.org/10.1007/s11146-015-9531-2

Phillips, P. C. B. (1995). Fully modified least squares and vector autoregression. Econometrica, 63(5), 1023-1078. https://doi.org/10.2307/2171721

Phillips, P. C. B., \& Hansen, B. E. (1990). Statistical inference in instrumental variables regression with I(1) processes. Review of Economic Studies, 57(1), 99-125. https://doi.org/10.2307/2297545

Robstad, $\varnothing$. (2018). House prices, credit and the effect of monetary policy in Norway: Evidence from structural VAR models. Empirical Economics, 54, 461-483. https://doi.org/10.1007/s00181-016-1222-1

Rubens, J., Bond, M., \& Webb, J. (1989). The inflation-hedging effectiveness of real estate. Journal of Real Estate Research, 4(2), 45-56. https://doi.org/10.1080/10835547.1989.12090578

Ryczkowski, M. (2019). Money, credit, house prices and quantitative easing - the wavelet perspective from 1970 to 2016. Journal of Business Economics and Management, 20(3), 546-572. https://doi.org/10.3846/jbem.2019.9859

Scherbina, A., \& Schlusche, B. (2014). Asset price bubbles: A survey. Quantitative Finance, 14(4), 589604. https://doi.org/10.1080/14697688.2012.755266

Shiller, R. J. (2009). Unlearned lessons from the housing bubble. The Economists' Voice, 6(7), 1-2. https://doi.org/10.2202/1553-3832.1616

Shimizu, C., Nishimura, K. G., \& Watanab, T. (2010). Residential rents and price rigidity: Micro structure and macro consequences. Journal of The Japanese and International Economies, 24(2), 282-299. https://doi.org/10.1016/j.jjie.2009.12.006

Sommer, K., Sullivan, P., \& Verbrugge, R. (2013). The equilibrium effect of fundamentals on house prices and rents. Journal of Monetary Economics, 60(7), 854-870. https://doi.org/10.1016/j.jmoneco.2013.04.017

Su, C., Yin, X., Tao, R., Lobonţ, O.-R., \& Moldovan, N.-C. (2018). Are there significant linkages between two series of housing prices, money supply and short-term international capital? - Evidence from China. Digital Signal Processing, 83, 148-156. https://doi.org/10.1016/j.dsp.2018.08.017 
Su, C.-W., Wang, X.-Q., Tao, R., \& Chang, H.-L. (2019). Does money supply drive housing prices in China? International Review of Economics and Finance, 60, 85-94. https://doi.org/10.1016/j.iref.2018.12.013

Tsai, I.-C. (2015a). Monetary liquidity and the bubbles in the U.S. housing market. International Journal of Strategic Property Management, 19(1), 1-12. https://doi.org/10.3846/1648715X.2014.973465

Tsai, I.-C. (2015b). Monetary policy and bubbles in the national and regional UK housing markets. Urban Studies, 52(8), 1471-1488. https://doi.org/10.1177/0042098014534904

Tsai, I.-C. (2020). Price rigidity and vacancy rates: The framing effect on rental housing markets. The Journal of Real Estate Finance and Economics. https://doi.org/10.1007/s11146-020-09791-4

Valadkhani, A., Nguyen, J., \& O’Brien, M. (2019). Asymmetric responses of house prices to changes in the mortgage interest rate: Evidence from the Australian capital cities. Applied Economics, 51(53), 5781-5792. https://doi.org/10.1080/00036846.2019.1619026

Wang, X.-Q., L.-N. Hao, Tao, R., \& Su, C.-W. (2020). Does money supply growth drive housing boom in China? A wavelet-based analysis. Journal of Housing and the Built Environment, 35, 125-141. https://doi.org/10.1007/s10901-019-09668-w

Yin, X.-C., Tao, R., Chai, K.-C., \& Su, C.-W. (2020). A revisit on linkage of hot money, money supply and housing prices in China. Journal of Housing and the Built Environment, 35, 617-632. https://doi.org/10.1007/s10901-019-09704-9

Zhang, C., Jia, S., \& Yang, R. (2016). Housing affordability and housing vacancy in China: The role of income inequality. Journal of Housing Economics, 33, 4-14. https://doi.org/10.1016/j.jhe.2016.05.005

Zorn, P. M. (1988). An analysis of household mobility and tenure choice: An empirical study of Korea. Journal of Urban Economics, 24(2), 113-128. https://doi.org/10.1016/0094-1190(88)90034-4 